\title{
Management Practices of SMEs Owners in Emerging Economies: A Gender Comparative Study
}

\author{
Nadia Laaraj ${ }^{1}$, Driss Ferhane ${ }^{2}$ \\ ${ }^{1}$ ESCA Ecole de Management, Casablanca, Morocco \\ ${ }^{2}$ Ecole Nationale de Commerce et de Gestion, Tangier, Morocco \\ Correspondence: Nadia Laaraj, ESCA Ecole de Management, Casablanca, 7, Rue Abou Youssef El Kindy, Bd. \\ Mly Youssef 20070 Casablanca, Morocco.
}

Received: June 14, 2019

doi:10.5539/ibr.v13n1p79
Accepted: October 10, 2019

Online Published: December 4, 2019

URL: https://doi.org/10.5539/ibr.v13n1p79

\begin{abstract}
The literature on management practices indicates that the company's performance depends largely on the skills of its leader, when the intuition of the latter is based on the instruments and rational management methods. The aim of this study is to analyse the relationship between the gender and management practices in terms of current operations (Production, marketing, finance, ...), identify the characteristics of the owner-manager of SMEs (male and female specific), and detect the points of divergence and convergence between women's and men's management. To do so, we conducted a theoretical analysis of the main concepts and indicators that allowed us to develop a research model. The analysis of the answers was based on a survey adressed to a sample of owner-managers. Our findings confirm that the personal characteristics of the owner-manager influence the management practices. The results of the comparison between the Moroccan ruling woman and man, show that there are no real differences in management style, but rather some shared values between them. This paper provides a theorical contribution on the link between the profile of owner-managers and management practices including the gender parameter. In terms of pratical contribution, it contribute to understand behavior of Moroccan SMEs owners and to show the importance of this two dimensions, the profil of owner managers and gender approach, it can be also considered as a recent study of the typical profile of owner-managers in an emerging country such as Morocco. We try, through this work, to contribute to this field of research which remains very fertile.
\end{abstract}

Keywords: female leader, male leader, gender, management practices, Moroccan, personal profile, SMEs

\section{Introduction}

Small and Medium-size Enterprises (SMEs) have a substantial contribution to the Moroccan economy, representing 95\% of Moroccan companies, according to statistics by the Confederation of SMEs. They are present in major sectors e.g., agriculture, industry, services and tourism, communication, transport, and financial services. In this context, given the nature of SMEs, the performance of the company is built upon the manager's influence. It is also this relative weight that manifests itself most prominently in the design and implementation of strategic decisions, which places the owner as our primary unit of analysis. The literature on management practices indicates that the performance of the company largely depends on the manager's abilities. Also, the manager's intuition draws upon instruments and rational management techniques.

Currently, Morocco is going through radical economic and social changes. According to the results of our investigations, few studies were identified on entrepreneurship specifically comparative studies. For this reason, we have chosen to work on this field of research and provide a recent description of the typical profile of Moroccan owner- managers (male and female) through a comparative study (based on gender approach) of management practices.

Based on these considerations, and on the premise that the manager is entirely responsible for the direction of the business, its success and its failure, the purpose of this research is to gain an in-depth understanding of the relationship between management practices and the owner-manager's characteristics as well as the points of divergence and convergence between male and female management.

The present study is two-leveled, with the first level being of a descriptive character, aiming at depicting the 
profile of Moroccan owner-managers. The second level is of an explanatory nature, seeking to verify the relationships between the manager's personal profile, the company characteristics and management practices, and the differences/similarities between male and female management practices within the organization. SMEs are often created by one owner-manager and their success, therefore, relies on their capabilities and vision of management more than any other factor (Thompson, 2009).

In our analysis, we provide an answer to the following two questions:

- Does the owner-manager's profile influence management practices?

- To what extent do female and male owner-managers converge in their management practices?

Our contribution proposes answers to these questions for a clearer understanding of the relationships potentially existing between the manager's profile and management practices and detect the points of divergence and convergence between women's and men's management. To proceed, the theoretical framework will depict the general context of SMEs. Then, after describing the methodology adopted in this article, the main results, along with discussions, will unfold.

\section{Literature Review}

The success of small companies heavily depends on the human capital of their owner-managers (Jones et al., 2007), they start to manage their companies with a unique set of human capital , including, for example, personal profile, level of education, experience, etc. As proven by Karami and al.( 2006), professional experience and education enable a entrepreneur to develop formal strategic plans. Moreover, personal characteristics impact the performance in terms of decision-making speed, decision type and strategy formulation. By contrast, Marshall (1995), demonstrates that gender-approach doesn't impact the leadership or the management of the company.

According to these prior theories, we will study whether, in the moroccan context, the manager's personal characteristics and the gender-approach influence the management practices.

\subsection{Owner-Manager's Profile and Management Practices}

Drucker (2011) defines management as "a specific practice that converts a mob into an effective, purposeful and productive group". However, there exist certain variables, on which depends the performance of management, such as structure, environment, culture, and context, which can be combined with the owner-manager's characteristics. This is the subject of our first theoretical part, where we attempt to present the variables related to the profile of the owner-manager.

\subsubsection{Age of the Owner-Manager}

Age of owner-managers often exists in research as a variable leading to differential results. Researchers have shown great interest in what stems from associations between the age of individuals and their cognitive system. For instance, Lacasse (1990) shows that maturity of entrepreneurship is reached at the age of 35-45, during which the entrepreneur has accumulated new skills and experiences helping to undertake crucial decisions. Business starting at a young age has been found to associate with higher mortality rates (Taylor, 1987). In regard to age differences and how they relate to gender, Welsch and Young (1984) show that female owner-managers in the United States are younger than their male counterparts at the start of their entrepreneurial project, with an average age of 25-40, against male owner-managers whose age at the start is over 43 . We expect a positive relation between the age of Moroccan owner-manager and management practices.

\subsubsection{Level of Training of the Owner-Manager}

Training is of crucial importance in the emergence of leaders in the company. The level of education represents a variable often privileged in the literature. In this context, Lalonde (1985) discusses the correlation between management practices and training in the business field as being of great significance. In the same study sampling owner-managers, of all the personal characteristics of the studied population, the level of education remains the most highly correlating variable with management practices. The level of education is expected to be positively related to management practices.

\subsubsection{Family History of the Owner-Manager}

Family environment, according to the literature, also appears to have a stimulating effect on the person's decision to start a business. Family, in general, is key in the desirability and credibility of an entrepreneurial action. For that, Leibenstein (1968) attests that being born into a family of business people appears to grant the entrepreneur a substantially higher evel of self-confidence compared to other entrepreneurs who come from a different family environment. Although the family is distinct as an independent variable forming the ground for 
businesses to start, its influence on management practices remains uncertain. In Lalonde's (1985) study, no significant relationship between family history and management practices was found. In the Moroccan context, we expect a negative relationship between the family history of the owner-manager and management practices. This is because, in the Moroccan culture, entrepreneurship and risk-taking are not sufficiently encouraged.

\subsubsection{Experience of the Owner-Manager}

According to Hisrich and Brush (1984), previous work experience can be a stimulating factor for entrepreneurial action. The transition from employee status to entrepreneur status can improve technical experience about suppliers, sectors, markets, etc., and can, subsequently, ensure good management of the company. Entrepreneurs, male and female, mostly had professional experience prior to the development of their own business. The difference resides solely on the type of experience (Zouiten, 2004). Professional experience can be compared to a springboard for business creation. These results are confirmed via other previous researches (Phillips, 2002; McClelland, 2004; Rachidi, 2006). Hence, the experience of the owner-manager and management practices relationship is expected to be positive.

\subsection{Gender and Management Practices}

Many comparative gender-related studies have shown the existence of significant gender-based differences in management styles (Rosener, 1990; Mukhtar, 2002; Bruni \& al., 2004). Other studies, on the other hand, have concluded that there is no gender difference in management styles (Xie and Whyte 1997). In the same vein, Marshall (1995) substantiates the idea that there exists no significant gender-based difference in leadership or management. According to Buttner (2001), the implementation of participative management is regularly exposed to research on female managers, who appear to aspire to build harmonious relationships with their employees by involving them in the decision-making process. Female managers believe that their employees' work will be more effective if they feel respected in the workplace. They choose to motivate their collaborators rather than control them. In terms of results, Jennings and Mc Dougald (2007) confirm that female owner-managers have smaller businesses and less turnover and benefits due to work-family conflicts compared to their male counterparts. In the same context, Riebe (2005) conducted a study in which female managers from the United States, Ireland, and Finland have created businesses exceeding half a million dollars in sale revenues. He concludes: "It would be impossible to extrapolate the size, the sector, the age or the nationality of these women-led enterprises based on the answers that they give to my questions about their management practice: the only determining factor of their answer was sex".

The researcher notices a style of management leaning toward the pursuit of flexibility, the establishment of a positive working environment, and an efficient style of team management.

The main criticisms around this theory, however, can be summarized by Gutek (1993) under the argument of gender roles as the way female managers are perceived by subordinates and how it influences the results of research and seems to be influenced more by stereotypes.

Other studies have shown that women's management is more oriented towards flexibility and create a family atmosphere with collaborators (Riebe, 2005). Du Rietz and Henrekson (2000), have shown that the difference in terms of performance between male and female firms is tending to disappear. Cornet et Constantinidis (2004), concluded that "if we look at the survival rate, it would be rather favorable for women, for growth and performance, no significant difference between the two sexes."

Chabaud (2013), shows that men make decisions by agreement with collaborators more than women. The difference is, however, significant, women managers make their decisions by agreement with their family, and less with employees, than men. Jennings et Mc Dougald (2007), suggest that women have smaller businesses and less turnover and benefits because of work-family conflict.

Our synthesis of the hypotheses is presented in the table below (Table1).

Table 1. Synthesis of the hypotheses

\begin{tabular}{cc}
\hline & Hypotheses \\
\hline H1 & The older the owner, the more management practices they use \\
\hline H2 & The higher the level of instruction, the more management practices they use \\
\hline H3 & The more experience the owner's family history has in entrepreneurial experience, the more management practices they \\
use.
\end{tabular}




\section{Methodology}

The present study was conducted using a questionnaire administered to a sample of 119 CEOs of whom $66.4 \%$ were male. The data collected was analyzed using SPSS Statistical Software Program. Our sample included organizations working with entrepreneurs within the biggest cities of Morocco. After checking the lists offered by these organizations, we compiled a database of more than 400 addresses of female and male entrepreneurs, of which 119 usable questionnaires were retrieved. Non-probability sampling method, particularly reasoned choice sampling, was adopted. For the collection of data, two methods were used-face-to-face interviews and online questionnaires using a web link shared with our target interviewees. The questionnaire consists of four parts, with the first part being information about the manager; the second, information about the company; the third, information about the environment of the company; and the last, information about management practices. As a prelude to the study, we developed and administered a pilot questionnaire in order to verify the credibility of advanced research hypotheses.

Regarding the diversity of SME definitions, we have chosen the one below to select our sample.

Indeed, are considered as SMEs companies that 1 :

- Employ less than 250 employees ;

- Have a turnover inferior to 27 million euros ;

Based on this definition, we present below some characteristics of our sample:

The sample includes mainly Moroccan privately-owned SMEs. This choice is justified by the evolution of their owners in business and the relations that may exist between the owner-managers and their business.

We consider individuals who are involved in their own business.

The selected SMEs for this study operate in the sectors of service, trade, industry and high technology. This is due to the fact that the majority of the Moroccan SMEs operate in these sectors and to the need to study companies with sufficient degree of complexity to justify management practices.

Our study targeted large cities in all regions of Morocco. Table 2 Figures 1 and 2 provide an overview of the delineation of the search field.

Table 2. Delineation of the search field

\begin{tabular}{cccc}
\hline Actors & Study field & Object of study & Research field \\
\hline $\begin{array}{c}\text { Woman manager } \\
\text { Man manager }\end{array}$ & SMEs & Management practices & Entrepreneurship \\
\hline
\end{tabular}

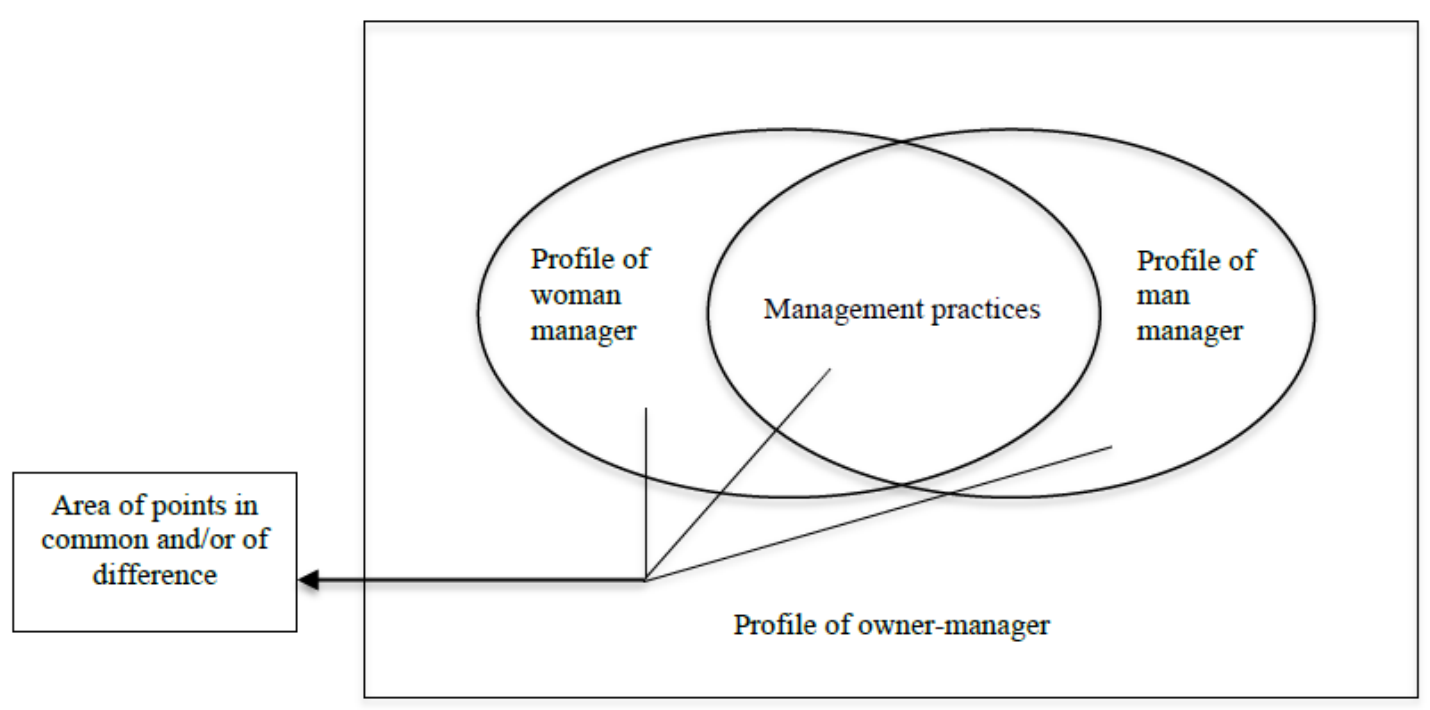

Figure 1. Overview of the delineation of the search field

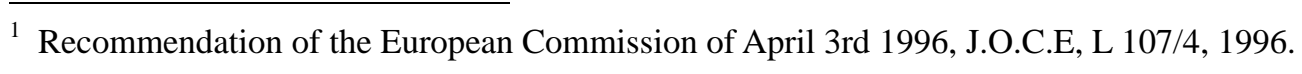




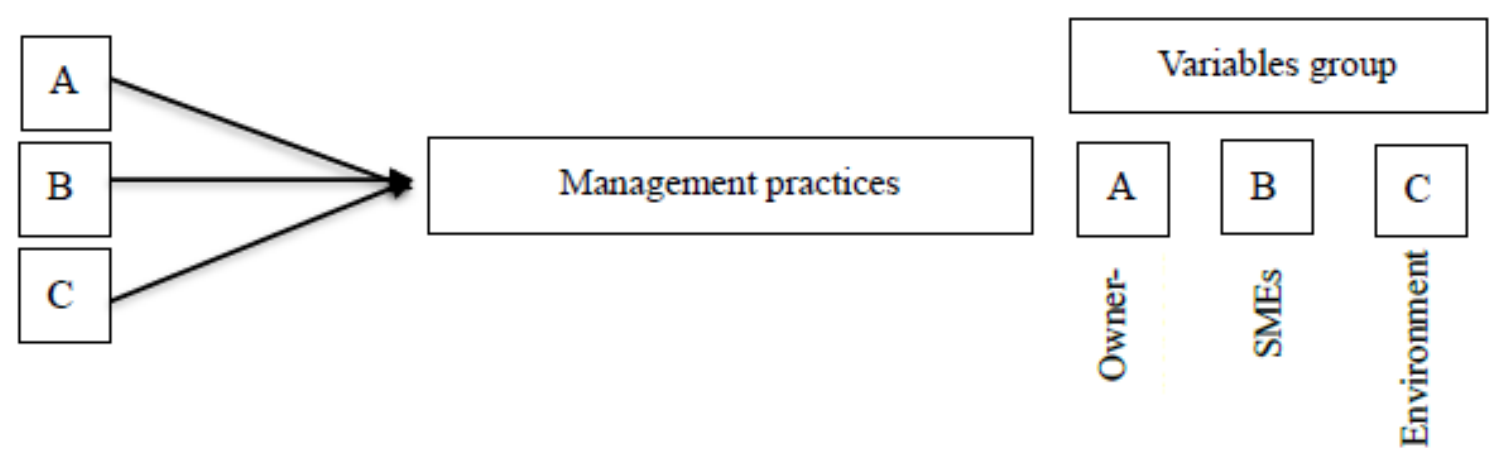

Figure 2. Synthesis of the methodological approach

The context analysis and literature review helped us develop a research model specifying potentially hypothetical relationships between the profile of female and male owner-managers and their management practices.

Our model of analysis is informed by the general framework provided by Campbell \& al. (1970). This framework is defined as a schematic portrait of the factors determining the expression of owner-manager management behaviors, which are considered in the prediction of managerial efficiency. The framework consists of a set of variables deemed relevant according to the literature on management practices.

It has four dimensions, the first of which includes variables related to the owner-manager profile, i.e., age, education, family history, and experience. The second concerns the gender dimension that we have chosen to present fully in our research model, given that this is a pivotal research question in our study. The third dimension concerns organizational environment and is added to the model to take into account the information that the owner-manager receives about the situation of the company (competition, customer, suppliers, bank, etc.), which acts on the dimensions of the model, but on which there is little control. The fourth dimension is about entrepreneurial, functional, and technical management practices. Our research model is presented in the figure below (Figure 3).

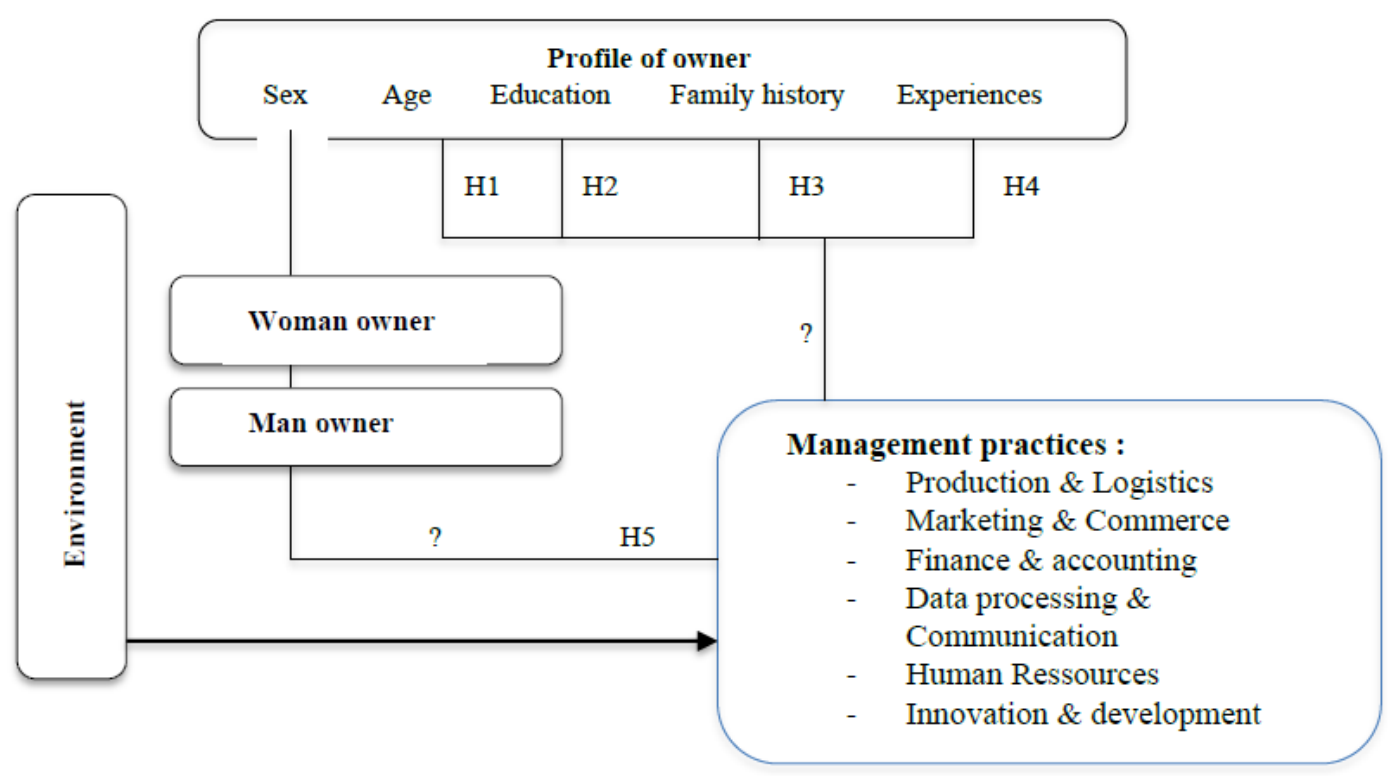

Figure 3. Research model 


\section{Findings}

We start this part by presenting the results of the corroboration of the hypotheses and the conceptual model. Then an overall synthesis of our results.

The validation of the first group of hypotheses (H1: The older the owner, the more management practices they use. H2: The higher the level of instruction, the more management practices they use, H4: The more accumulated experience, the more efficiently they use management practices) confirms the influence of the owner-manager's personal profile on management practices. The personal profile is a positive indicator of the potential ability to take on new responsibilities. This finding is more palpable within SMEs since the manager has direct power over the company's activities, the limited number of employees, and the small size of current operations. The success or the failure of SMEs, therefore, depends in the first place on the leader. Similar to what has been suggested by other researchers, Sweeney (1982) shows that small businesses are worth what the people are worth. If they are good they can do exceptional things.

In accordance with the literature, our results appear to show that age, status, level of education, and experience are the personal characteristics most likely to influence the owner-manager's management practices. The results have also showcased that during the start-up period, chances of success come mainly from the adequacy of the manager for the project (Fortin, 1990).

Hypothesis $\mathrm{H} 1$, which has been validated, states that the older the owner-manager, the more management practices they use and the better they manage their business. It should be noted that age is a factor likely to discriminate individuals in their projects in general and in terms of business creation and management in particular. In other words, the older the owner-manager, the more sufficient experience, competence, and self-confidence they gain. This result corroborates the work of Taylor (1987), who holds that starting a business at an early age leads to a higher mortality rate due to insufficient experience, capital, and know-how.

We have also validated Hypothesis $\mathrm{H} 2$, which suggests that the higher the level of education, the more management practices used. In other words, an owner-manager who has a high level of education is more likely to be able to assess the environment and to adapt to it. The findings accord with those of Mayer and Goldstein (1961), who explain that the success rate of firms is associated with higher levels of training among managers.

Similar results obtained by Robidoux and Gamier (1973) substantiate the theory, the higher the manager's level of education, the higher the growth rate. In SMEs, better training of the manager ensures the growth of this structure since SME managers must be able to play the role of the owner, accountant, buyer, financier, etc. on a daily basis.

Also validated, Hypothesis $\mathrm{H} 4$ suggests a relationship between the owner-manager's professional experience and management practices. It is true that this relationship has been widely cited in the literature as an important variable for the crucial role of experience in the decision to start a business. However, it should be noted that this is experience in the same field, and therefore its degree is measured by the number of years the individual has worked in the environments related to the subject area.

No link, however, between family history and management practices has been found. The rejection of hypothesis (H3: The more experience the owner's family history has in entrepreneurial experience, the more management practices they use) can be explained by the following reasons: The literature on the manager's family as having an influential effect on the decision-making process is developing; family environment has a ripple effect on the decision of project starters. This finding is consistent with the work of several researchers, amongst whom is Leibenstein (1968), who states that being born into a family of business people fosters the entrepreneur's level of self-confidence. However, similar influence on management practices or company performance is non-existent; Lalonde's (1985) research results did not detect any significant relationship between a family of business and management practices at the time of starting a business. According to the literature, the manager's family partly accounts for the difficulty or success that the entrepreneur is predisposed to.

Hypothesis (H5: Management practices vary according to the owner-manager's gender) has been partly validated. We relate to the relationship between the manager's gender and management practices. It should be noted that the notion of "female management style" has drawn the attention of many researchers over the last years. Many comparative gender studies have shown the existence of significant differences between female and male management styles (Rosener, 1990; Mukhtar, 2002; Bruni \& al. 2004). Other studies, on the other hand, have maintained that gender has no differential effect on management styles (Xie and Whyte 1997).

The four hypotheses retained are represented on the final model. The refuted hypothesis has been removed (Figure 4). 


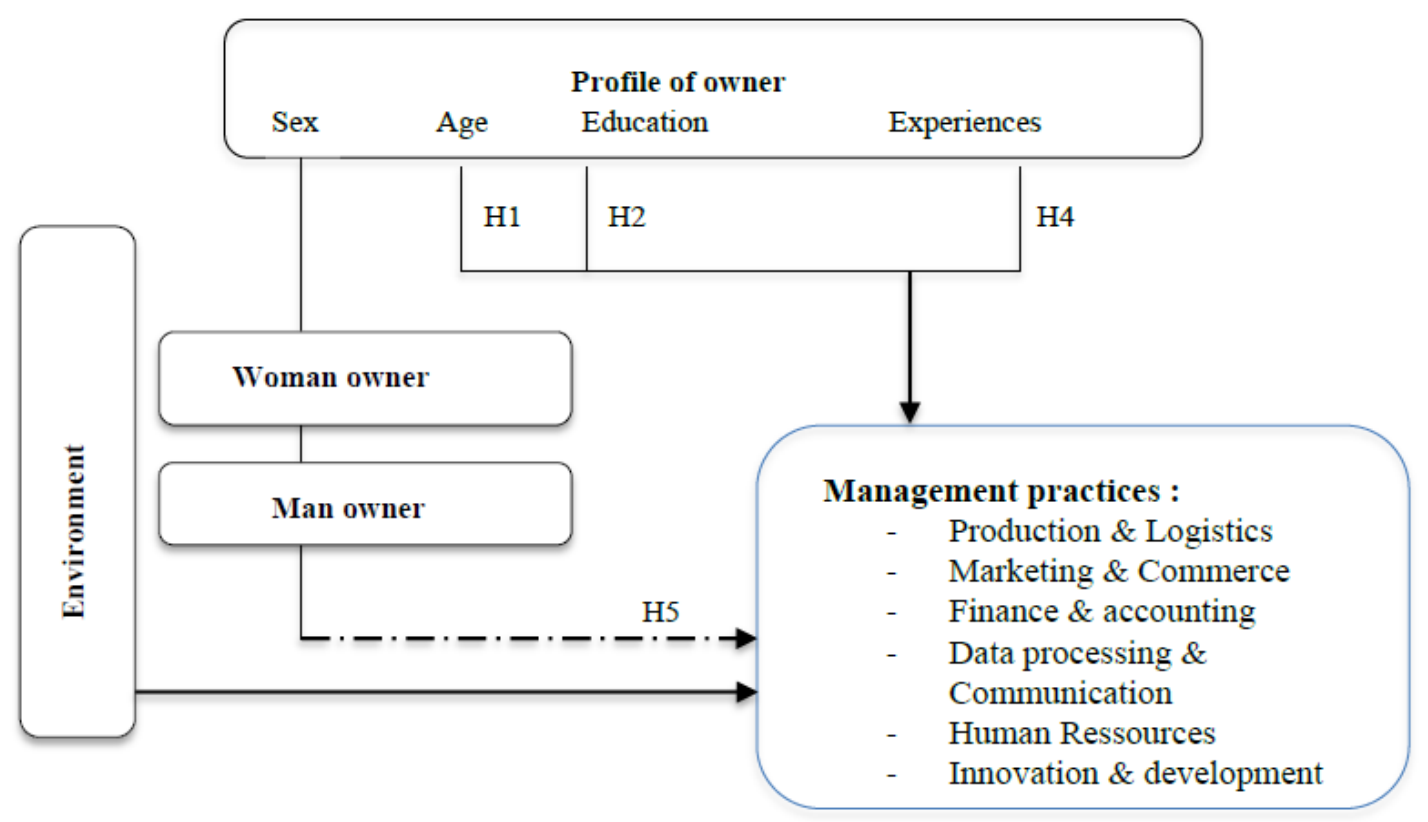

Figure 4. Developed conceptual model after corroboration of hypotheses

On the descriptive stage, which was the premise of this research, the main objective was to compare enterprises on the gender scale, particularly in terms of the profiles of SME owner-managers and their relationships with the environment. After this generic observation, we will present the results of our study taking into consideration gender as a variable.

On the whole, the study shows that the differences are generally minimal; these findings corroborate the work of other researchers (MarshXie and Whyte 1997), who contributed with substantial literature to the topic of gender-based differences and similarities, which did not result in any significant difference at the level of the skills and practices used to assess potential for leadership or management. The initial results from this study show that the age of female owner-managers is the same as that of their male counterparts, with an average of 31-50. A large majority of them had professional experience before having the status of owner-manager, which supports the work of Lacasse (1990), who indicates that maturity of entrepreneurship is reached at the age of 35-45. This is because the owner-manager has enough time to accumulate new skills and experience. For the researcher, it is the combination of two factors age and experience that favors the decision to start a business.

A second observation concerns Moroccan female and male managers having a high level of education (university and professional), being married, and having children. In general, the initially elicited results do not reveal any significant differences in the profiles of Moroccan female and male leaders. Regarding the characteristics of their businesses, we found that the majority of female-owned businesses operate in the trade and services sector-a finding that also corroborates the work of Hisrich and Peters (1991), which holds that "the nature of the activity performed differs according to whether the company is created by a man or a woman. The findings also confirm Bardasi's (2011) study, which shows that female owner-managers create companies in less buoyant sectors. Also found is that female-created businesses are a relatively recent phenomenon. In Morocco, the emergence and development of female entrepreneurship were witnessed only in the 1980s. This recent emergence explains the lack of reliable statistics on the reality of Moroccan female entrepreneurs. As regards staff, the majority of female-created businesses manage a workforce of approximately 100 employees.

Jennings and Mc Dougald (2007) suggest that female managers have smaller businesses and less turnover and benefits on account of work-family conflicts. Their male counterparts, on the other hand, can immediately embark on major creative projects. This finding supports other similar research studies (Wilson \& al. 2007; Maes $\&$ al. 2014), which maintain that male managers are more adventurous in their careers, as opposed to female managers, whose socially-associated family constraints and responsibilities lead to the unlikeliness to develop projects with high potential.

With regard to environment as another affecting variable, female managers have been found to manage their 
relations with their environment similar to their male counterparts, with a few peculiarities. For example, as to the management-bank relationship, particularly the procurement of cash facilities, a large majority of female leaders declared that they cannot easily benefit from these facilities due to the lack of confidence of the bankers. This supports the results from Lightstone (1997), which reveal that "the rate of refusal of loans remains higher for companies whose owners are women (23\%) compared to men (14\%)".

The same results concerning the management-suppliers relationship were found; a majority of female leaders admitted their inability to quickly earn the confidence of their new suppliers. This finding accounts for cultural aspects, wherein women have long been primarily assigned domestic work from a very young age.

Our results show that there are no significant differences between female management and male management. The exception resides in the former having a different approach towards human resources. Consistently with Buttner (2001), the results prove that female management is more of a participative management style, given the non-controlling and motivating nature of this style.

\section{Conclusion}

The proposed model has provided answers to the following general question: Does the owner's profile influence their management practices? And to what extent do female and male owners converge in their behavior of management?

This general question has been broken down into three sub-questions designed to explore each dimension of the model.

For each of these dimensions, a literature review and a theoretical argument were presented, which allowed for hypotheses and relations between the variables. Following the proposed model, two sets of assumptions were issued and verified. The paper adopted a comparative approach, which enables a typical profile of Moroccan female managers to be compared to their male counterpart.

The results have revealed minimal differences in female management that are characterized by a more motivating and less controlling relationship with their staff. The study is also a reflection on management practices in Moroccan SMEs, particularly on female entrepreneurship as a model of economic and social growth.

This work has some limitations as it has studied just the 15 biggest Moroccan cities . Furthermore, we couldn't take into consideration the spatial and cultural dimension of the different regions in terms of the behavior of women managers. As a perspective, we expect to proceed to a gender study of the entrepreneurial behavior in each project phase, namely the pre and post implementation, considering the geographical and cultural dimension of each region. Moreover, our results can also be extended to study the behavior of non-moroccan managers, by comparing Morocco to another emerging county with a similar context. The objective will be, for example, to compare the degree of evolution, experience, etc.

\section{Acknowledgements}

We thank the anonymous referees for their useful comments and suggestions. We would also like to thank ESCA Ecole de Management for their continued support.

\section{References}

Bardasi, E., Sabarwall, S., \& Terrell, K. (2011). How do female entrepreneurs perform? Evidence from three developing regions. Small Business Economics, 37(4), 417-441. https://doi.org/10.1007/s11187-011-9374-z

Bruni, A., Gherardi, S., \& Poggion, B. (2004). Entrepreneur-mentality, gender and the study of women entrepreneurs. Journal of organizational change management, 3, 256-268. https://doi.org/10.1108/09534810410538315

Buttner, E. H. (2001). Examining female entrepreneur's management style : an application of relational frame. Journal of Business Ethics, 29(3), 253-269. https://doi.org/10.1023/A:1026460615436

Campbell, J., Dunnette, M., Lawler, E. E., \& Weik, K. E. (1970). Managerial behavior, performance and effectiveness. New York, MacGraw-Hill.

Chabaud, D. (2013). Qui sont vraiment les dirigeants de PME., Caen, Editions Management et Sociétés.

Cornet, A., \& Constantinidis, C. (2004). Entreprendre au féminin. Une réalité multiple et des attentes différenciées. Revue française de gestion, 151, 191-204. https://doi.org/10.3166/rfg.151.191-204

Drucker, P. F. (2011). The ecological vision reflections on the American condition. New Brunswick, NJ, Transaction Publ. 
Du Rietz, A., \& Henrekson M. (2000). Testing the Female Underperformance Hypothesis. Small Business Economics. Kluwer Academic Publishers.

Fortin, P. A. (1990). Les entrepreneurs de demain. PME magazine de l'entrepreneuriat. Québec, p7.

Gutek, A. (1993). Changing the Status of Women in Management. Applied Psychology: an International Review, 42(4), 301-311. https://doi.org/10.1111/j.1464-0597.1993.tb00746.x

Hisrich, R. D., \& Brush, C. (1984). The woman entrepreneur: management skills and business problems. Journal of Small Business Management, 22(1), 30-37.

Hisrich, R. D., \& Peters, M. P. (1991). Entrepreneuriat: lancer, élaborer et gérer une entreprise. Economica.

Jennings, J. E., \& Mc Dougald, M. S. (2007). Work-family interface experiences and coping strategies: implications for entrepreneurship research and practice. Academy of Management Review, 32(3), 747-760. https://doi.org/10.5465/amr.2007.25275510

Jones, O., Macpherson, A., Thorpe, R., \& Ghecham, A. (2007). The evolution of business knowledge in SMEs: conceptualizing strategic space, Strategic Change, 16, 281-294.

Karami, A., Analoui, F., \& Kakabadse, N. K. (2006). The CEOs' characteristics and their strategy development in the UK SME sector: an empirical study, The Journal of Management Development, 25(3), 316-324. https://doi.org/10.1108/02621710610655800

Lacasse, R. M. (1990). La petite entreprise au Canada: le cas particulier de l'entrepreneuriat féminin dans le secteur manufacturier (Unpublished doctoral dissertation). University of Nice Sophia Antipolis.

Lalonde, C. (1985). Caractéristiques et pratiques de management des propriétaires dirigeants dont l'entreprise a été mise en faillite: une étude en contexte régional au Québec (Unpublished doctoral dissertation). University of Laval.

Leibenstein, H. (1968). Entrepreneurship and development. Proceedings of American Economic Review, 58(2), $72-83$.

Lightstone, T. (1997). Les PME au Canada : Énoncé de leurs besoins, de leurs attentes et de leur satisfaction envers les institutions financières. Association des banquiers canadiens, vol.1.

Maes, J., Leroy, H., \& Sels, L. (2014). Gender differences in entrepreneurial intentions: a TPB multi-group analysis at factor and indicator level. European Management Journal, 31(5), 784-794. https://doi.org/10.1016/j.emj.2014.01.001

Marshall, J. (1995). Gender and Management: A Critical Review of Research. British Journal of Management, 6, 53-62. https://doi.org/10.1111/j.1467-8551.1995.tb00138.x

Mayer, K., \& Goldstein, S. (1961). The first two years: problems of small firms growth and survival. Small Business Administration. Washington, D.C.

McClelland. (2004). Irish female entrepreneurs: mapping the route to internationalization. Irish journal of management, 25(2), 93-107.

Mukhtar. (2002). Differences in male and female management characteristics: a study of owner-manager businesses. Small business economics, 3, 289-310. https://doi.org/10.1023/A:1015235402335

Phillips, D. J. (2002, September 19). A genealogical approach to organizational life chances: the parent progeny transfer among Silicon Valley law firms 1946-1996. Administrative science quarterly, 3, 474-506. https://doi.org/10.2307/3094848

Rachidi, F. (2006). L'entrepreneuriat féminin au Maroc : une étude exploratoire. Laboratoire ERMMES (Toulon). EDHEC Nice France.

Riebe, M. (2005, June 18). The leadership style of women entrepreneurs : an alternative model of successful management practices. Paper presented at the fiftieth international Council Congress for Small Businesses (ICSB), Washington.

Robidoux, J., \& Gamier, G. (1973). Facteurs de succès et faiblesses des petites et moyennes entreprises au Québec, spécialement des entreprises utilisant des techniques de production avancées. Sherbrooke: University of Sherbrooke.

Rosener, J. B. (1990). Ways Women Lead. Harvard Business Review, 119-125.

Sweeney, G. (1982). Les nouveaux entrepreneurs, Petites entreprises innovatrices. Les Editions d'Organisation, 
Paris, pp.64-79.

Taylor, H. L. (1987). Déléguer: La clé de l'efficacité. Paris, Eyrolles.

Thompson, E. R. (2009). Individual Entrepreneurial Intent: Construct Clarification and Development of an Internationally Reliable Metric. Entrepreneurship: Theory and Practice, 669-694. https://doi.org/10.1111/j.1540-6520.2009.00321.x

Welsch, P., \& Young, E. C. (1984). Information search patterns among Hispanic Entrepreneurs. Journal of Small Business Management, 39-48.

Wilson, F., Kickul, J., \& Marlino, D. (2007). Gender, Entrepreneurial Self Effecacy, and Entrepreneurial Career Intentions: Implications for Entrepreneurship Education. Entrepreneurship: Theory and Practice, $31(3), 387$. https://doi.org/10.1111/j.1540-6520.2007.00179.x

Xie \& Whyte. (1997). Gender differences among managers and non-managers : an analysis of assessment data. Revue canadienne des sciences de l'administration, 3, 340-353. https://doi.org/10.1111/j.1936-4490.1997.tb00140.x

Zouiten, J. (2004). L'entrepreneuriat féminin en Tunisie. Paper presented at the international congress of CEDIMES, Alexandrie.

\section{Copyrights}

Copyright for this article is retained by the author(s), with first publication rights granted to the journal.

This is an open-access article distributed under the terms and conditions of the Creative Commons Attribution license (http://creativecommons.org/licenses/by/4.0/). 